\title{
Out of the Norwegian glaciers: Lendbreen-a tunic from the early first millennium AD
}

Marianne Vedeler ${ }^{1} \&$ Lise Bender Jørgensen ${ }^{2}$

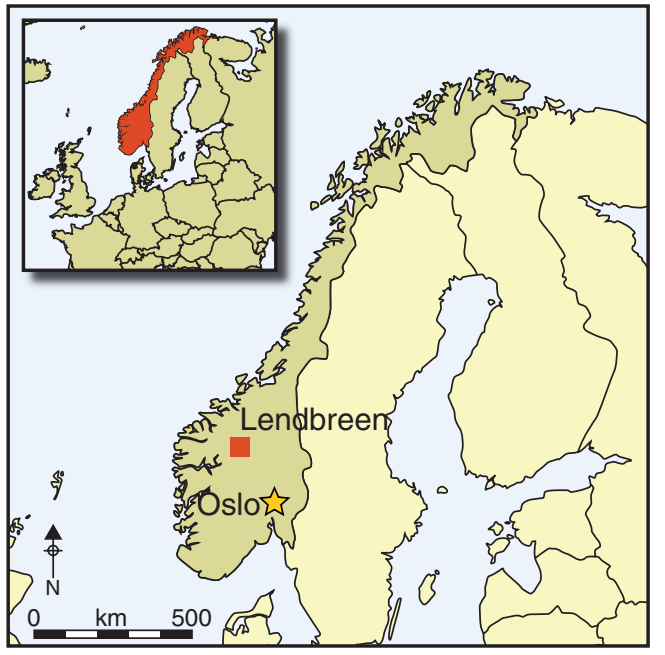

As the temperature rises each year, the assemblages of prehistoric hunters emerge from the ice. Archaeologists in Norway are now conducting regular surveys in the mountains to record the new finds. A recent example presented here consists of a whole tunic, made of warm wool and woven in diamond twill. The owner, who lived in the late Iron Age (third-fourth centuries AD), was wearing well-worn outdoor clothing, originally of high quality.

Keywords: Norway, first millennium AD, tunic, diamond twill

\section{Discovery}

Due to global warming, rapid melting of snow patches and glaciers is taking place in the mountains of Norway as in other parts of the world (Hansen et al. 1985; Spindler 1995; Ceruti 2004; Hare et al. 2004; Suter et al. 2005; Farbregd 2009), and hundreds of archaeological finds emerge from the ice each year. The upland areas in which snow patches are found are little frequented by humans today, but hunting and trapping have been carried out there since prehistoric times. Reindeer often congregate on snow patches in late summer to regulate their body temperature and to avoid parasitic insects, making them attractive hunting grounds (Callanan 2010: 49-50). Artefacts from multiple periods were deposited on the ice patches, many of them made of organic material rarely preserved elsewhere; ice patches provide exceptional preservation conditions for textiles.

1 Museum of Cultural History, University of Oslo, PO Box 6762, St. Olavsplass, 0130 Oslo, Norway (Email: marianne.vedeler@khm.uio.no)

2 Department of Archaeology and Religious Studies, Norwegian University of Science and Technology, N-7491 Trondheim, Norway (Email: lise.bender@ntnu.no) 


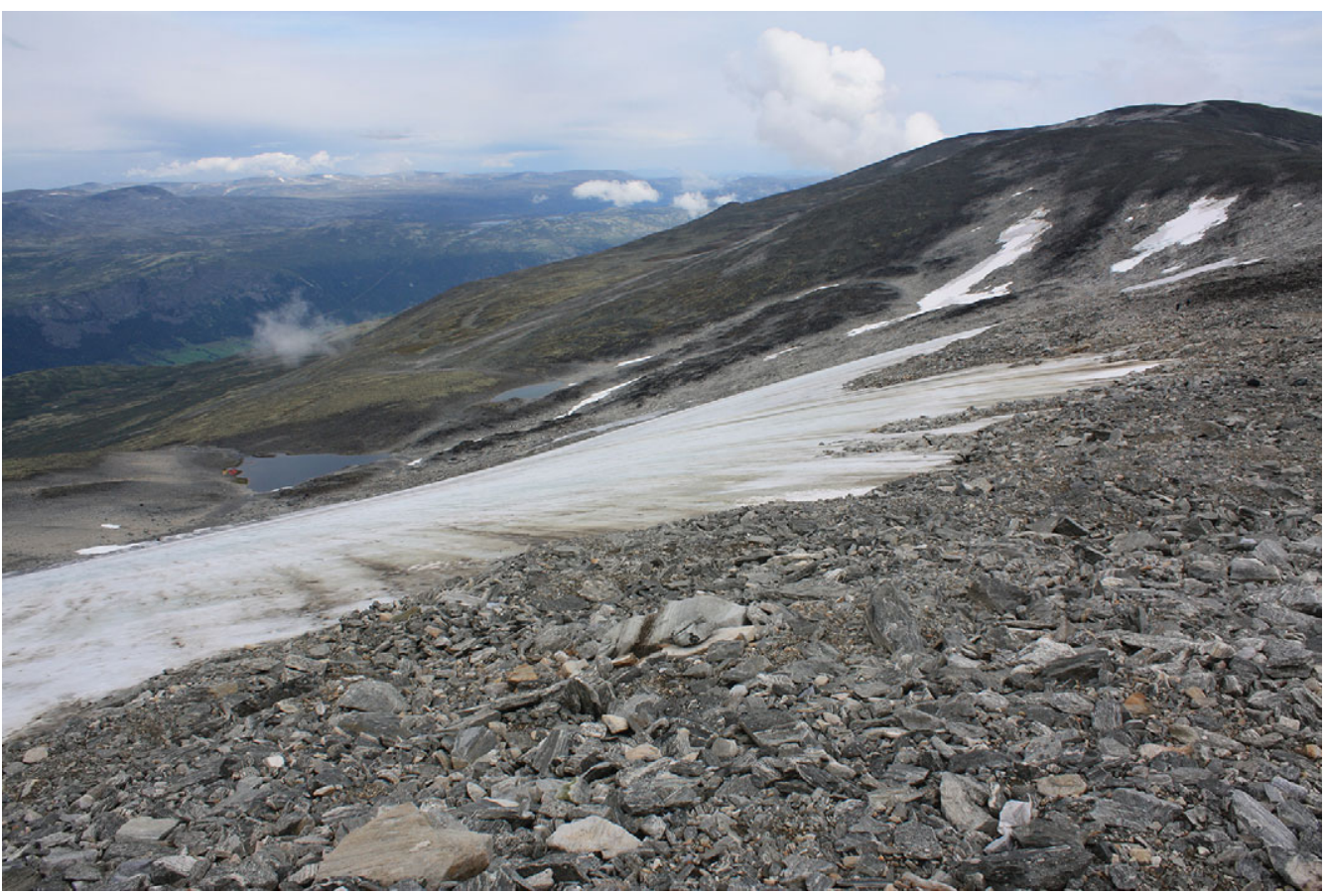

Figure 1. The Lendbreen glacier in Oppland, Norway. Photo: Vivian Wangen.

In August 2011, archaeologists from Oppland's Glacier Archaeology Rescue Program were conducting surveys approximately $1900 \mathrm{~m}$ asl, on the Lendbreen glacier, Lomseggen, in Oppland County, Norway (Figure 1), when they encountered what appeared to be a crumpled-up piece of textile approximately $0.58 \times 0.29 \mathrm{~m}$ in size (Figure 2). It lay in a pit at the upper edge of the ice patch on the surface of barren scree, exposed by thawing, and appeared randomly bundled up rather than intentionally folded. It bore traces of close association with horse dung (Pilø forthcoming).

When unfolded and studied, it proved to be a very well-preserved tunic, its fabric partly bleached where exposed to the sun and wind (Figure 3). Radiocarbon dating shows that the tunic was made between AD 230 and 390 (Tamers \& Hood 2011; Figure 4). Only a handful of well-preserved tunics from this period have been found in Europe, and therefore the new find is of great significance for dress and textile production and how these reflect the interplay between northern Europe and the Roman world.

No other artefacts were found in the immediate surroundings, and the textile is considered an isolated find with no demonstrable relationship to other objects found on the site so far. The area of the find has been used for hunting over a long period up to modern times. Weapons, hunting and camping equipment and horse dung, as well as a variety of personal gear including textile remains, are among the finds that now emerge from the ice. At Lendbreen, a large variety and number of artefacts from different periods have been recovered, most of them connected to ancient hunting strategies, such as so-called 'scaring sticks'. These were set up in lines to drive wild reindeer towards a kill site (Finstad \& Pilø 2010: 24-39).

(C) Antiquity Publications Ltd. 


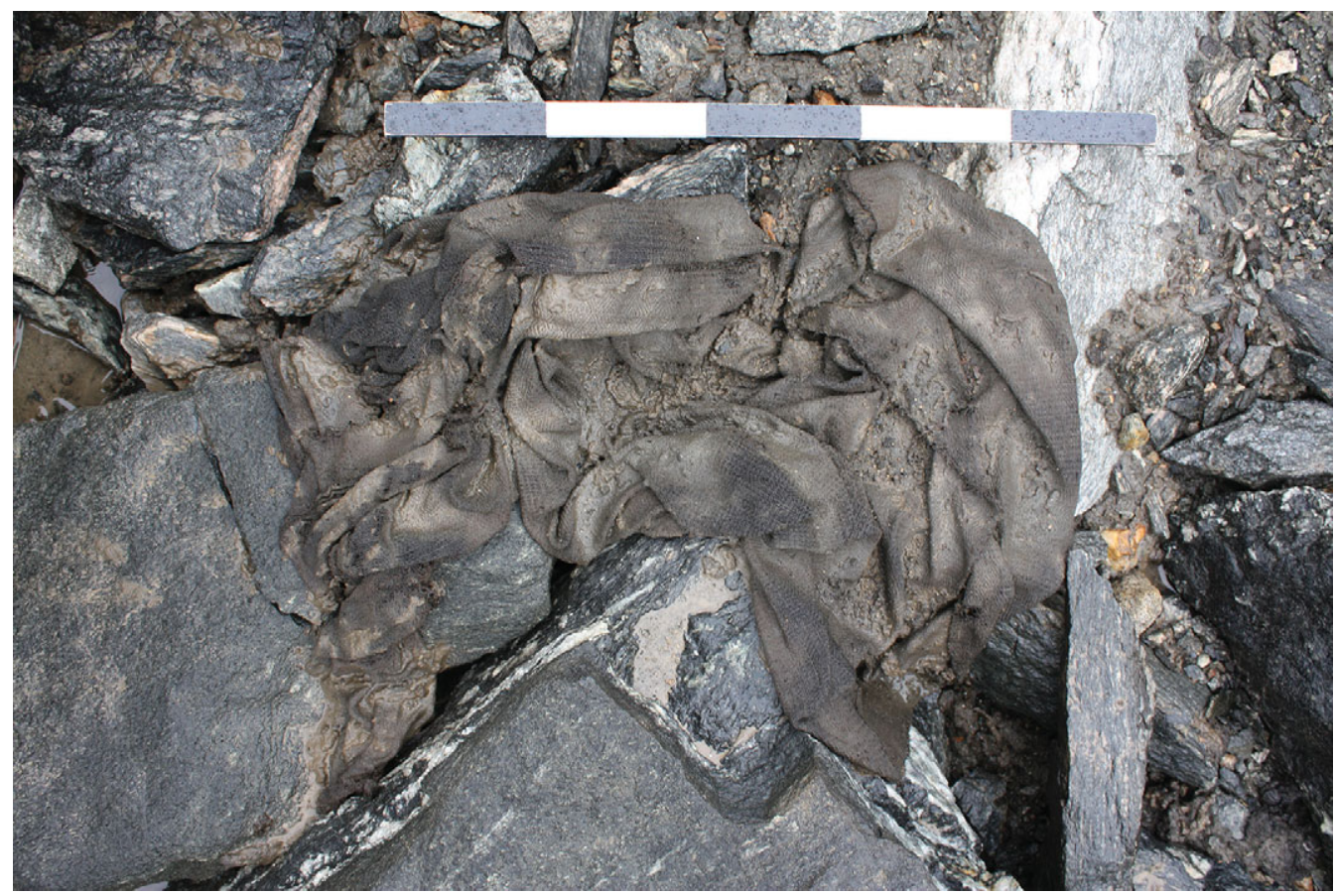

Figure 2. The Lendbreen tunic in situ. Photo: Vivian Wangen.

\section{Description of the garment}

\section{Material}

Examinations with a Scanning Electron Microscope and light microscopy show that the fibres of the material are generally very well preserved: they are still rounded and scales are visible (Rast-Eicher 2011: 1). Two different fabrics are present and the fibre tips indicate that both were made of lamb's wool or wool from adult sheep moulting annually. Fibre diameters are exceptionally fine in parts of both the sleeves and the body, but a few thick fibres are visible here and there. This is due to careful sorting of the wool. Including a certain amount of long, coarser fibres probably made spinning easier. The high proportion of thin and delicate fibres results in a soft, high-quality product. The largest difference in quality is between warp and weft in the main fabric. The warp is made of fine white wool with thick fibres in brown and black. The light weft contains no traces of coarse fibres, while the dark weft is made of a coarser selection of wool (Rast-Eicher 2011). There is no doubt that the wool was carefully chosen for both fabrics, and that both quality and natural pigmentation were taken into consideration.

\section{Fabric}

The body section of the tunic is woven in 2/2 diamond twill (Figure 5). The same fabric is also used in the smaller of the two patches on the back. Due to uneven exposure to the sun, the textile surface colour appears patchy, but a closer look reveals that the fabric has

(C) Antiquity Publications Ltd. 

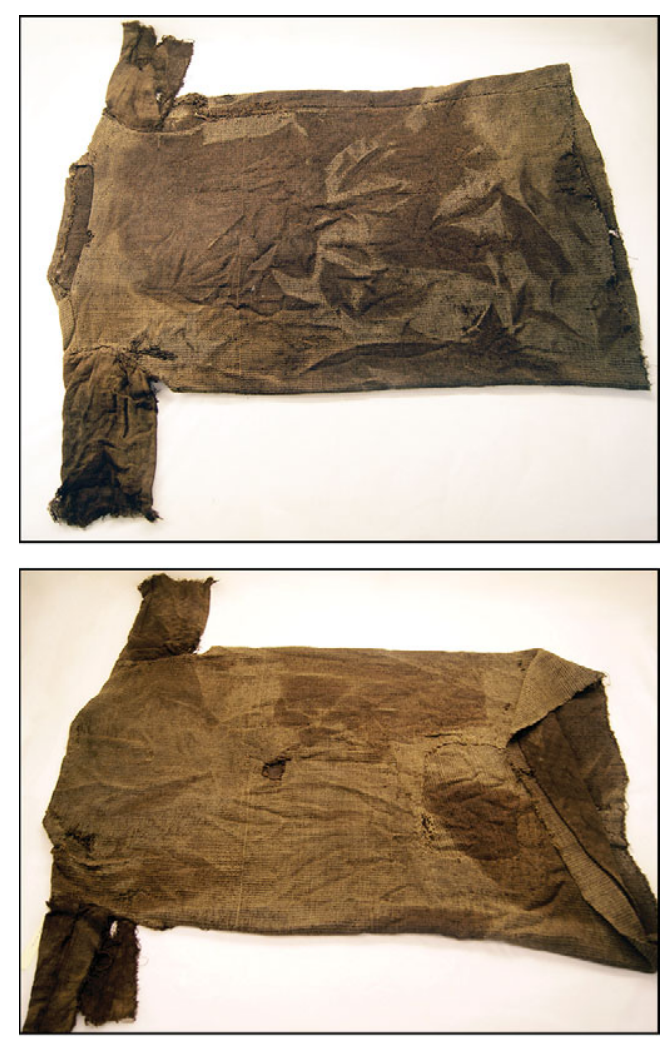

Figure 3. The Lendbreen tunic, front (above) and reverse (below). Museum of Cultural History, University of Oslo, C57874. Photo: Marianne Vedeler. been deliberately and evenly mottled. This effect is caused by the weft, consisting of two light and two dark brown alternating threads made of naturally pigmented wool in shades of light beige and dark brown (Rast-Eicher 2011: 1). While the dark yarns are generally $\mathrm{z}$-twisted, the light weft yarns shift to s-twisted in an area near the lower edge. The warp consistently holds the same colour as the light weft. The alternating colouration of the weft causes the diamond pattern to almost disappear. It is barely visible when the fabric is dry. A weaving fault (four light weft threads instead of two) runs all the way around the mid-section of the body sheet. The diamond twill pattern is irregular, reversing after between 8 and 11 threads in the warp-direction and between 12 and 30 threads in the weft direction. The warp runs vertically through the garment.

The sleeves are made from a 2/2 diamond twill, but a different fabric than the body section. The fabric is a slightly lighter shade as threads in one system are less pigmented. The twist direction is $\mathrm{z} / \mathrm{s}$ in the right sleeve. However, an area above the longitudinal seam in the left sleeve shows shifting twist directions in one thread system, probably the weft. The pattern unit is also uneven in this fabric. Shifts in the pattern appear after 10-17 threads in one thread system and after 10-14 threads in the second (Figure 6).

A tablet-woven band on the inside of the side seam in the body section was made with four tablets. Both light brown z-twisted wool yarn and a darker brown yarn with corresponding spinning are used. The band is hidden inside the tunic and only visible from the reverse. Narrow tablet-woven edges of this type are quite common in Roman period textiles and appear to have been used both for starting borders and, as in this case, for selvedges (Schlabow 1976; Hald 1980; Ræder Knudsen 2011).

\section{Form of the garment}

The tunic is relatively short and constructed from a simple cut (Figure 7; Table 1). The chest girth measures approximately $1.08 \mathrm{~m}$. By modern size standards, the tunic would thus fit a slender man, 1.7-1.76m in height (International Organization for Standardization 1981). Some parts bear traces of hard wear and tear, especially the areas around sleeve openings, the hip area and at the back. Some parts of the lower edge and neck opening, as well as both

(C) Antiquity Publications Ltd. 


\section{CALIBRATION OF RADIOCARBON AGE TO CALENDAR YEARS}

(Variables: $\mathrm{C} 13 / \mathrm{C} 12=-23.4:$ lab. mult $=1$ )

Laboratory number: Beta-304746

Conventional radiocarbon age: $1740 \pm 30$ B P

2 Sigm a calibrated result: Cal AD 230 to 390 (Cal BP 1720 to 1560) (95\% probability)

In tercept data

Intercepts of radiocarbon age with calibration curve: Cal AD 260 (Cal BP 1690) and

Cal AD 290 (Cal BP 1660) and

Cal AD 320 (Cal BP 1630)

1 Sigma calibrated result: Cal AD 250 to 340 (Cal BP 1700 to 1610 ) ( $68 \%$ probability)

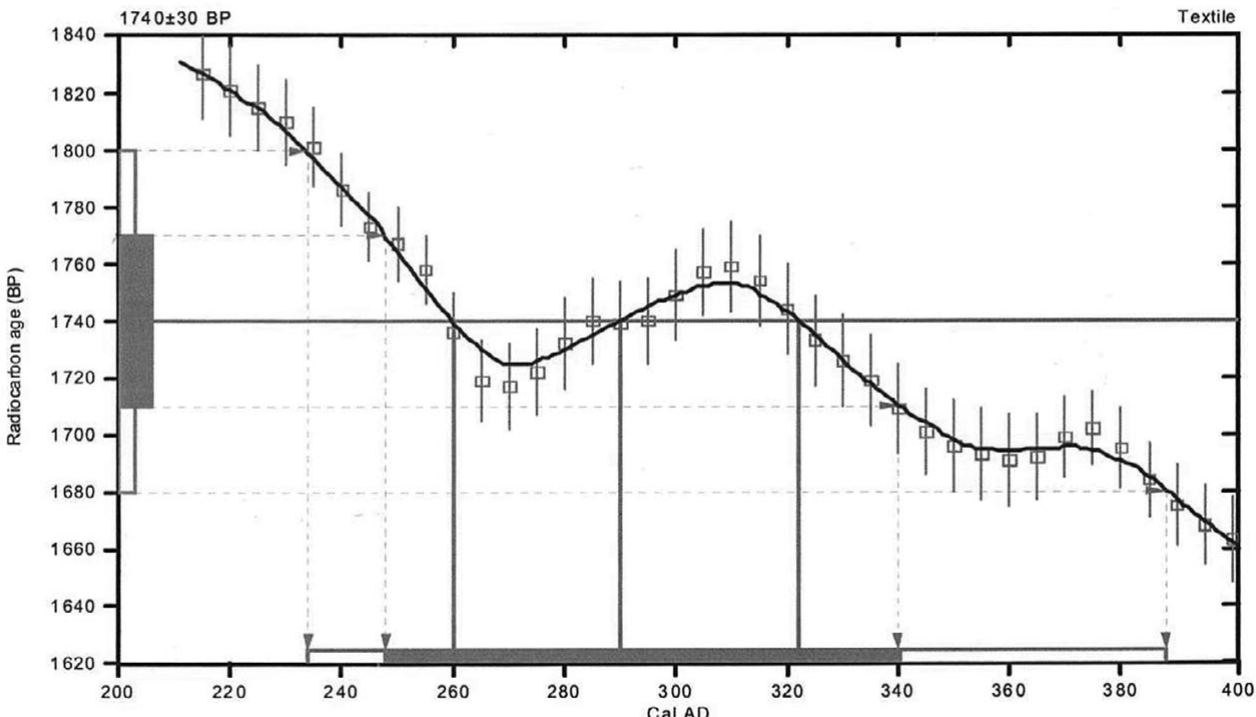

References:

Database used

INTCALO4

Calibration Database

IN TCAL 04 Radiocarbon Age Calibration

IntCal04: Calibration Issue of Radiocarbon (Volume 46, nr 3, 2004).

Mathematics

A Simplified Approach to Calibrating C14 Dates

Talma, A. S., Vogel, J. C., 1993, Radiocarbon 35(2), p317-32

\section{Beta Analytic Radiocarbon Dating Laboratory}

4985 S.W. 74th Court.Miami, Florida 33155·Tel:(305)667-5167·Fax: (305)663-0964·E-Mail: beta@radiocarbon.com

Figure 4. Radiocarbon dating of the tunic from Lendbreen.

sleeves, are also fragmented. The main body section is in one piece. The sleeves were set in curved sleeve openings. The body section is slightly broader toward the lower end. This effect was achieved by cutting the fabric on top of the sleeve openings and then making a hem on each side.

The body section is folded on the wearer's right side and has a seam on the left (A in Figure 7). The neck opening is a so-called boat neck, a flat, straight neckline (C) Antiquity Publications Ltd. 


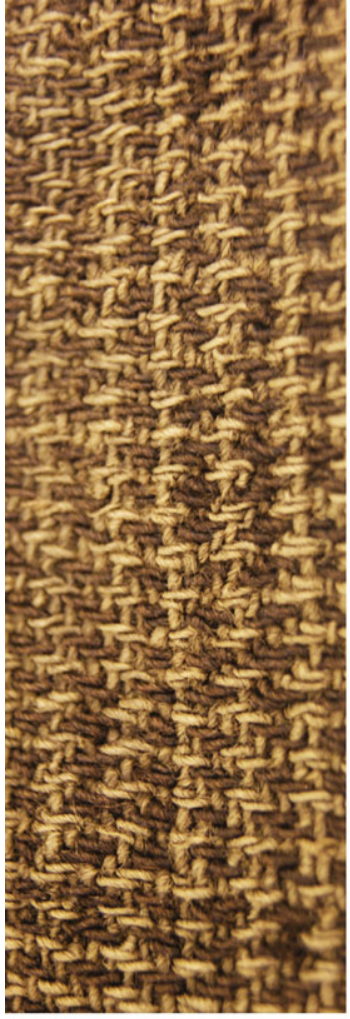

a

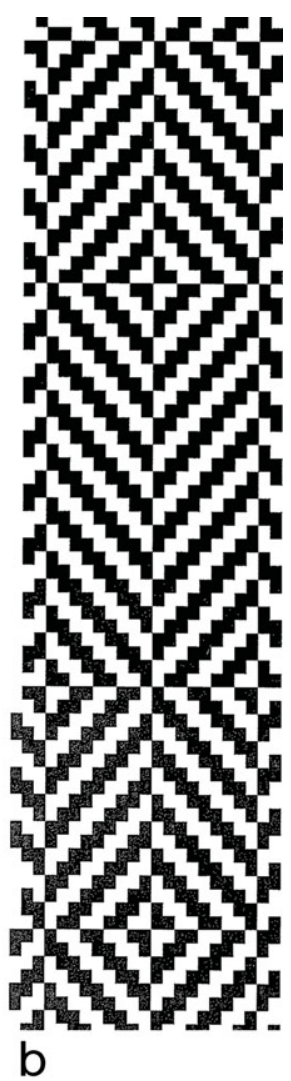

Figure 5. a) Detail of the Lendbreen fabric showing the diamond twill of the body section. Photo: Marianne Vedeler; b) pattern of the irregular diamond twill shown in the photo. Pattern drawing: Lise Bender Jorgensen. with simple folds at the front and back. The forward position of the shoulder seams results in a small upraised rim at the back of the neck opening, about $40 \mathrm{~mm}$ higher than the shoulder seams (B). The sleeve openings are curved. They are relatively narrow, only $0.21 \mathrm{~m}$ wide from the armpit to the top of the shoulder. The openings are folded with a $10 \mathrm{~mm}$ wide double hem (C). The sleeves were sewn on to the main part with a different quality of thread (D). The lower part of the tunic gives the impression of a well-used garment, repaired at least twice. The lower edge of the back is even and hemmed (E). The hem $\mathrm{E}$ is fragmented in several places, but the edges themselves are only moderately damaged in these parts. At the front of the tunic, the edges are uneven and shredded. Both sleeves are partly torn off, now measuring $0.2-0.26 \mathrm{~m}$ from the shoulder. The remaining parts of the sleeves are narrow and tube-formed, made of a single piece of fabric joined along the back with a seam running approximately $50 \mathrm{~mm}$ from the back part of the shoulder and sloping slightly forward at the lower end (G). The left sleeve has a nearly rectangular fragmented area in the lower part.

The tunic has been repaired with two patches. The square patch (1) is made from the same fabric as the body part of the tunic. The patch was sewn on from the reverse $(\mathrm{H})$. A similar seam placed approximately $50 \mathrm{~mm}$ outside the first holds the patch in place. To reinforce this, another larger patch (2) was put on top of the first, also on the reverse. It is not visible from the right, although it covers approximately $0.24 \times 0.41 \mathrm{~m}(\mathrm{I}-\mathrm{J})$.

\section{Use}

The Lendbreen tunic is a first glimpse of the kind of warm clothing used by hunters frequenting the ice patches of Scandinavia in pursuit of reindeer. It had no buttons or fastenings, but was simply drawn over the head like a sweater. Presumably it was combined with some form of weatherproof outer clothing, leggings or trousers, and footwear that could have been one-piece leather shoes. The patching shows that this was not the first stage of the tunic's life; indeed, the hunter who abandoned it may not have been its first owner.

It is quite possible that the tunic was originally sleeveless, and that the sleeves were added at a later stage of its life. For the first repair, the mender used a patch of the same fabric 


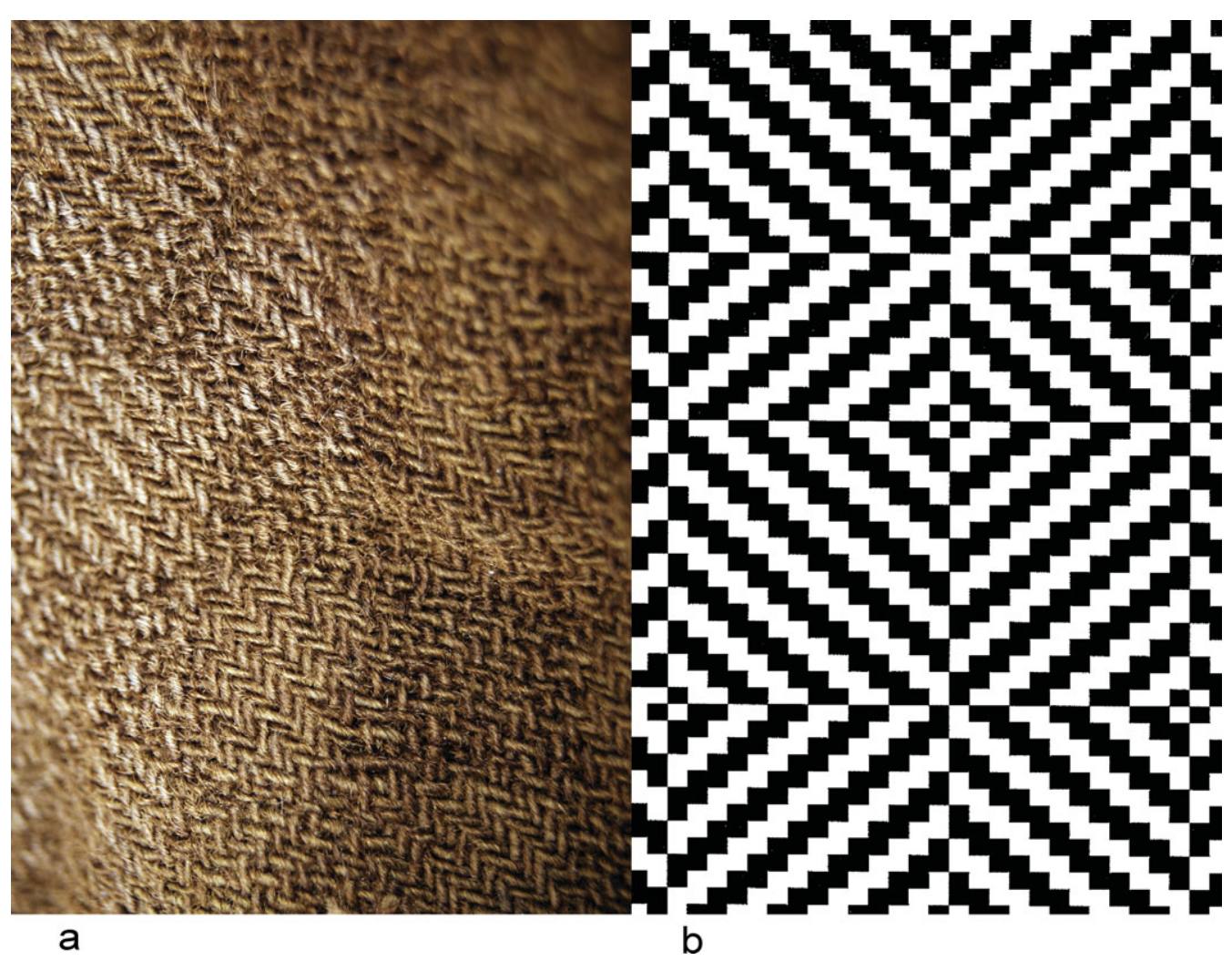

Figure 6. a) Detail of the sleeve fabric of the Lendbreen tunic. Photo: Marianne Vedeler; $\boldsymbol{b})$ pattern of a section of the irregular diamond twill. Pattern drawing: Lise Bender Jorgensen.

as used in the body section, while the second patch derived from the fabric used for the sleeves. The seams on this second patch are made with the same yarn as used for sewing on the sleeves. This suggests that the sleeves were added at the same time as the tunic was repaired for the second time.

\section{Comparable garments}

Well-preserved garments are rare in archaeological contexts, except in arid, waterlogged or frozen conditions. In Europe, complete items of clothing have been found in the Bronze Age oak-log coffins of Denmark (Broholm \& Hald 1940); in a number of acid bogs in Denmark, northern Germany, the Netherlands and Sweden, mainly dated to the preRoman and Roman Iron Age (von Post et al. 1925; Schlabow 1976; Hald 1980; Comis 2003; Mannering et al. 2010); two Villanovan tombs from Verucchio, Italy (Stauffer 2012); and in a Roman burial at Les Martres-de-Veyre in France (Desrosiers \& Lorquin 1998). The skin garments of Ötzi (Similaun Man) are another example (Spindler 1995). Other parts of the world, notably the frozen tombs of Central Asia and the Andes, and the deserts of the Middle East, have supplied further rich finds (see e.g. Vogelsang-Eastwood 1993; Mallory \& Mair 2000; Ceruti 2004; Pritchard 2006).

(C) Antiquity Publications Ltd. 


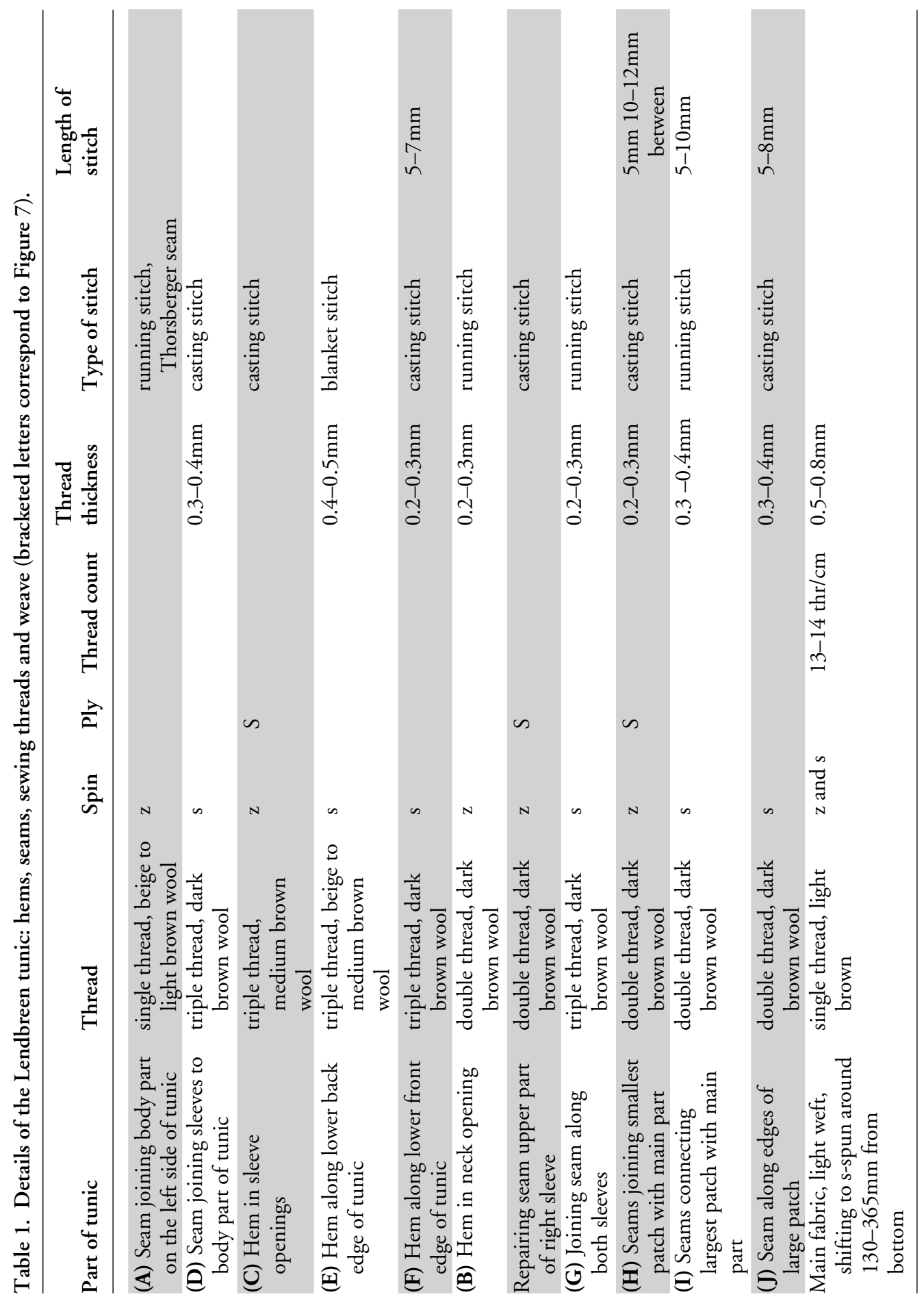

C) Antiquity Publications Ltd. 


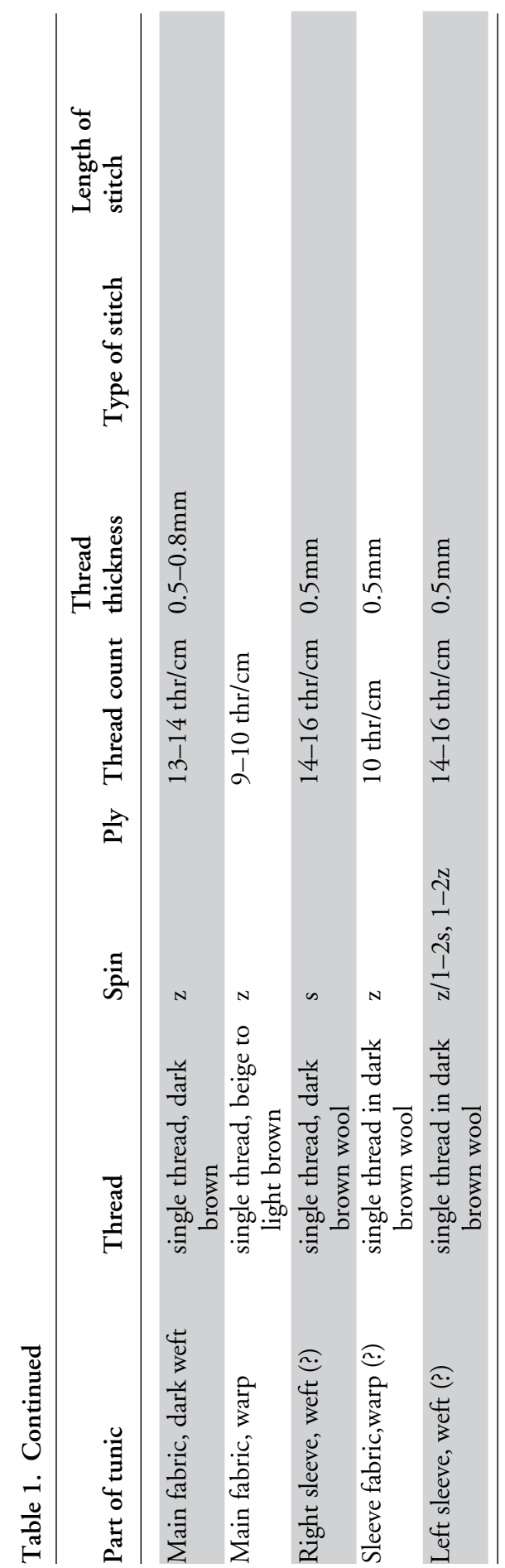

(C) Antiquity Publications Ltd. 


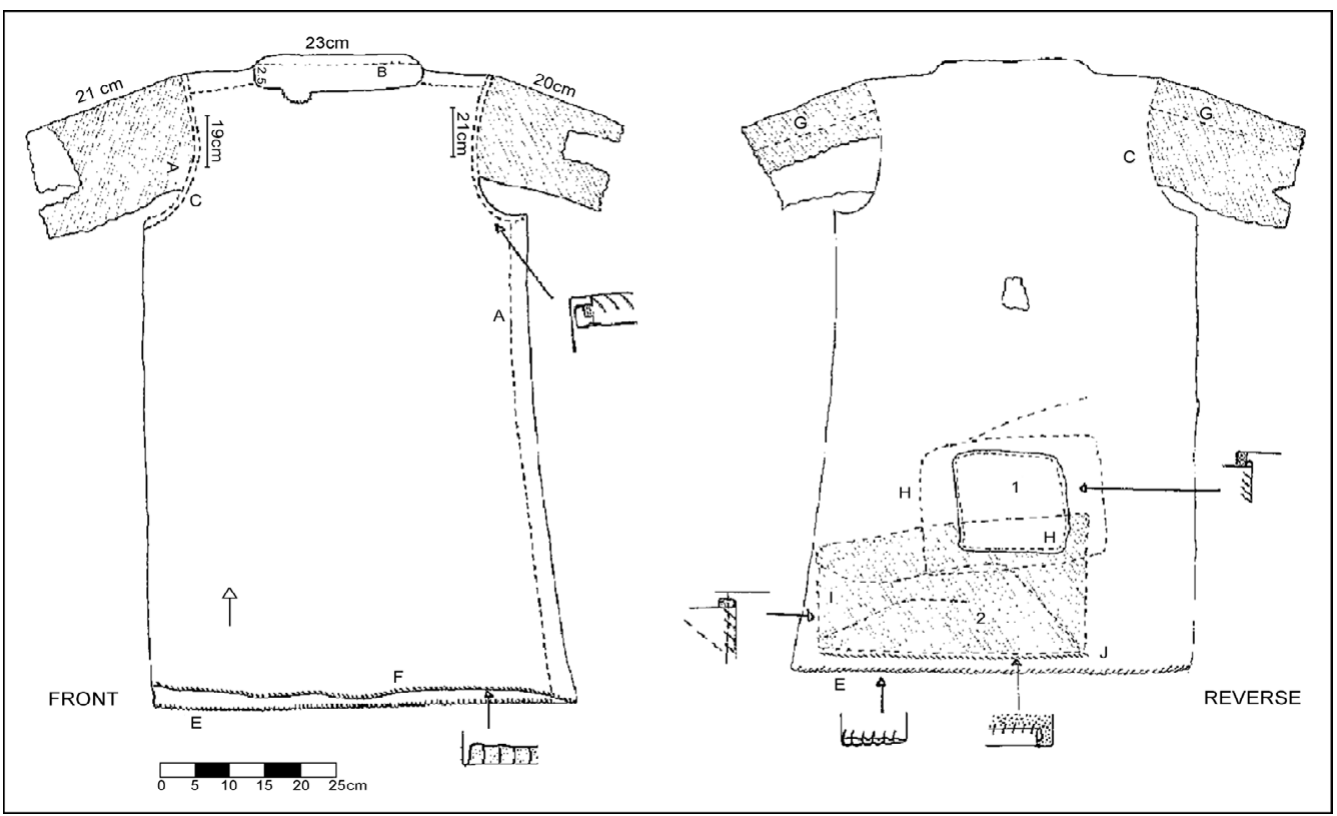

Figure 7. Measured diagram of the tunic from Lendbreen, front and reverse. Total length of body section: 920mm; width of body section: top: $445 \mathrm{~mm}$, middle: $555 \mathrm{~mm}$, bottom: $610 \mathrm{~mm}$. Outer patch in same fabric as body section: around 190mm high $\times 290 \mathrm{~mm}$ wide. Drawings: Marianne Vedeler.

The closest parallel to the Lendbreen tunic as regards cut, weave and date is the Thorsberg tunic (Figure 8). This is tailored probably from one length of fabric, and consists of four parts: front, back and two sleeves (Schlabow 1976: figs. 137-42). The fabric is diamond twill with a repeat of 20/18 that only shows a few irregularities. A tablet-woven starting border is to be found at one lower back end of the tunic, and-like Lendbreen - the warp of the Thorsberg tunic thus runs vertically through the item (Möller-Wiering 2011: 43). In its sleeves and shoulders, the Lendbreen tunic makes use of the so-called Thorsberger seam found in several contemporary garments (Möller-Wiering 2011: 43), a seam construction that prevents the raw edge from unravelling (Figure 9).

Another useful parallel is the sleeved tunic from Reepsholt (Fuhrmann 1942). This was woven to shape, beginning with a tablet-woven starting border at one sleeve, adding further warp threads (and starting borders) for the body section and reducing them again before making the second sleeve. This way of constructing woven-to-shape garments is well known from the Roman world (Granger-Taylor 1982). The Reepsholt tunic has a z-spun warp, while the weft alternates between two s-spun threads and one z-spun; moreover, the s-spun wefts are made from darker fibres than the $\mathrm{z}$-spun warp and weft yarns, giving it a mottled appearance.

The Thorsberg tunic derives from an early first millennium weapon deposit excavated in 1859-61, along with several other well-preserved garments (Engelhardt 1863). Due to the early date of the excavation it cannot be established with certainty which of a series of deposits made during the second and third century AD the garments belong to, but the most likely candidate is one dated to the first half of the third century AD (Möller-Wiering 2011:

(C) Antiquity Publications Ltd. 


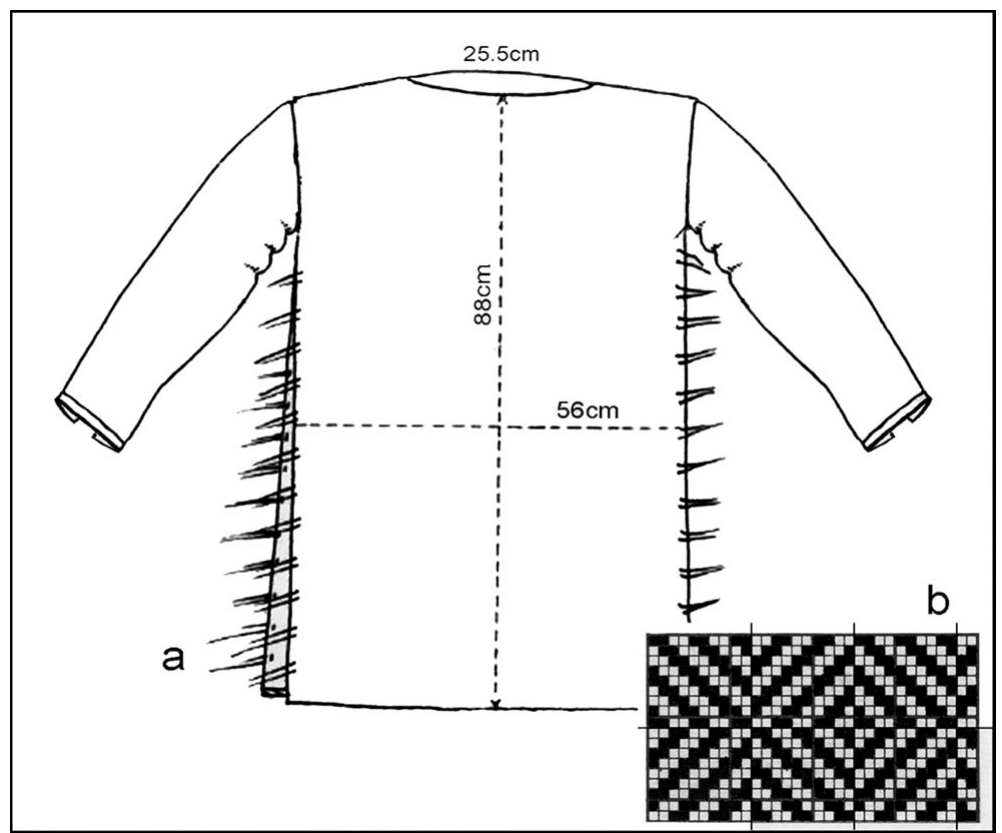

Figure 8. a) The Thorsberg tunic, redrawn by Aud Beverfjord after Schlabow 1976; b) pattern of diamond twill with a regular repeat of 20/18, as in the Thorsberg tunic. Pattern drawing: Lise Bender Jørgensen.

Table 2. Roman Iron Age tunics from northern Europe.

\begin{tabular}{|c|c|c|c|c|c|}
\hline Site & Date & Weave & Spin & Thread count & Edges \\
\hline $\begin{array}{l}\text { Lendbreen } \\
\text { (Norway) }\end{array}$ & AD $230-390$ & $\begin{array}{l}\text { Diamond } \\
\text { twill }\end{array}$ & $\mathrm{z} / \mathrm{z}(\mathrm{s})$ & $9-10 / 13-14$ & Tablet-woven \\
\hline $\begin{array}{l}\text { Thorsbjerg } \\
\text { (Germany) }\end{array}$ & $\begin{array}{l}\text { Second-third century } \\
\text { AD }\end{array}$ & $\begin{array}{c}\text { Diamond } \\
\text { twill }\end{array}$ & $\mathrm{z} / \mathrm{s}$ & $15.5 / 15$ & $\begin{array}{l}\text { Tablet-woven starting } \\
\text { border }\end{array}$ \\
\hline $\begin{array}{l}\text { Reepsholt } \\
\text { (Germany) }\end{array}$ & $\begin{array}{l}\text { Assumed date within } \\
\text { first four centuries AD }\end{array}$ & $2 / 2$ twill & $\mathrm{z} / 2 \mathrm{~s}, 1 \mathrm{z}$ & $9-10 / 12$ & $\begin{array}{l}\text { Tablet-woven starting } \\
\text { borders, reinforced } \\
\text { selvedges }\end{array}$ \\
\hline $\begin{array}{l}\text { Marx-Etzel } \\
\text { (Germany) }\end{array}$ & AD $45-125$ & $2 / 2$ twill & $\mathrm{z} / \mathrm{s}$ & & Tubular selvedge \\
\hline $\begin{array}{l}\text { Obenaltendorf } \\
\text { (Germany) }\end{array}$ & AD 260-380 & $\begin{array}{l}\text { Half- } \\
\text { basket }\end{array}$ & $\mathrm{z} / \mathrm{z}$ & $11 / 23$ & $\begin{array}{l}\text { Starting cord, reinforced } \\
\text { selvedges }\end{array}$ \\
\hline
\end{tabular}

41). This makes the Thorsberg tunic contemporary with the Lendbreen tunic (Table 2). The Reepsholt tunic has not been ${ }^{14} \mathrm{C}$ dated, but is considered to be of early first millennium date (Möller-Wiering 2011: 109). Two sleeveless tunics from Obenaltendorf and Marx-Etzel also belong to the first millennium (Schlabow 1976; Möller-Wiering 2011: 108).

Diamond twills appear frequently in contemporary Scandinavian graves (Bender Jørgensen 1986), and are particularly common in the weapon deposits of Thorsberg in

(C) Antiquity Publications Ltd. 


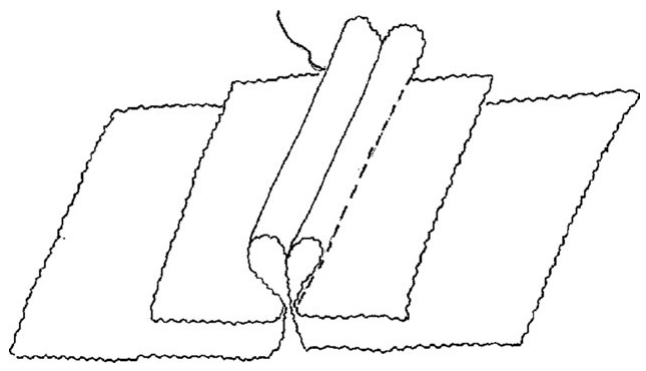

Figure 9. The 'Thorsberger seam', redrawn after MöllerWiering 2011. northern Germany and Illerup Aadal in Jutland, Denmark (Möller-Wiering 2011). They also make up a large part (at least 462) of the textiles found in the Roman fort of Vindolanda in the UK (Wild et al. 1998: 89), and have been found in a series of other Roman forts and towns in north-western Europe and in the Near East (Bender Jørgensen 1992: 133-36, 2004: 94; Sheffer \& Granger-Taylor 1994: 209; Cardon 2003: figs. 339, 354; Cardon et al.

2011: 332). Few parallels to the Lendbreen pattern are available, although that of the Reepsholt tunic is related; another may be found in a checked fabric from Karlby Mose dated to between $200 \mathrm{BC}$ and AD 140 (Hald 1980: 46; Mannering et al. 2010). The irregular pattern of the Lendbreen diamond twills is also a characteristic feature of the diamond twills found in the weapon deposit of Illerup Aadal (Möller-Wiering 2011: 11). As the defeated army whose gear ended up in Illerup Aadal allegedly derived from Norway, this is worth further consideration. Is it possible that irregular diamond twills were a Norwegian variety of a high quality fabric appreciated both in northern Europe and in the Roman world?

\section{Conclusion}

The tunic from Lendbreen provides valuable new information about dress and clothing in the early first millennium $\mathrm{AD}$. Cut, construction and fabric show similarities to wellknown, contemporary finds, yet it carries its own distinct signature. Perhaps one might have expected a difference between the Thorsberg tunic, which supposedly belonged to a high-ranking officer, and the clothing of a mountain hunter. The wear and tear of the Lendbreen tunic is the main difference between the two. The hunter's tunic was of good quality, but was well-worn at the time of its discard. It was, however, still serviceable, and a less discerning wearer might well have found it useful. It could, for example, be cut up and used to patch other garments, and the circumstances of its deposition were not necessarily deliberate abandonment. These aspects raise the interesting question of whether reindeer hunting was carried out by members of the elite, using old items of clothing for the hardship of the mountains. Another possibility is that it had been handed down from its first owner to another person of lower status.

The Lendbreen tunic is not the only textile item recovered from the Norwegian ice patches. Currently, approximately 50 fragments await dating and analysis and, as global warming progresses, more can be expected. They promise to shed further light on dress, textile design and textile production in the first millennium $\mathrm{AD}$ — and earlier.

\section{Acknowledgements}

The survey that led to finding the Lendbreen tunic was part of the Glacier Archaeology Rescue Program in Oppland, a joint operation by the Oppland County Municipality and the Museum of Cultural History (MCH), University of Oslo, led by field director Lars Pilø from Oppland County Municipality. Special thanks are due to Margunn Veseth, conservator at the Museum of Cultural History, who helped with co-counting the diamond

(C) Antiquity Publications Ltd. 
twill pattern and to Vivian Wangen at $\mathrm{MCH}$ for constructive advice and information about the find-spot. Dr Antoinette Rast-Eicher, ArcheoTex, analysed the wool. The ${ }^{14} \mathrm{C}$ dating was carried out by Beta Analytic Radiocarbon Dating Laboratory for the Glacier Archaeology Rescue Program. We also thank the Editor and two reviewers for useful suggestions.

\section{References}

BENDER JøRGENSEN, L. 1986. Forhistoriske textiler $i$ Skandinavien. København: Det Kongelige Nordiske Oldskriftselskab.

- 1992. North European textiles until AD 1000. Aarhus: Aarhus University Press.

- 2004. A matter of material: changes in textiles from Roman sites in Egypt's Eastern Desert. Antiquité Tardive 12: 87-99.

Broholm, H.C. \& M. Hald. 1940. Costumes of the Bronze Age in Denmark. Copenhagen: Nyt Nordisk.

Callanan, M. 2010. Northern snow patch archaeology, in C. Westerdahl (ed.) A circumpolar reappraisal: the legacy of Gutorm Gjessing (1906-1979) (British Archaeological Reports international series 2154): 43-54. Oxford: Archeopress.

CARDON, D. 2003. Chiffons dans le désert: textiles des dépotoirs de Maximianon et Krokodilô, in $\mathrm{H}$. Cuvigny (ed.) La route de Myos Hormos, volume 2: 619-59. Le Caire: Institut Français d'Archéologie Orientale.

Cardon, D., H. Granger-Taylor \& W. NowiK. 2011. What did they look like? Fragments of clothing found at Didymoi: case studies, in $\mathrm{H}$. Cuvigny (ed.) Didymoi. Une garnison romaine dans le desert Oriental d'Égypte, 1: les fouilles et le matériel: 273-395. Le Caire: Institut Français d'Archéologie Orientale.

Ceruti, C. 2004. Human bodies as objects of dedication at Inca mountain shrines, north-western Argentina. World Archaeology 36: 103-22.

Comis, S. 2003. Prehistoric garments from the Netherlands, in L. Bender Jørgensen, J. Banck-Burgess \& A. Rast-Eicher (ed.) Textilien aus Archäologie und Geschichte. Festschrift für Klaus Tidow: 193-204. Neumünster: Wachholtz.

Desrosiers, S. \& A. Lorquin. 1998. Gallo-Roman period archaeological textiles found in France, in L. Bender Jørgensen \& C. Rinaldo (ed.) Textiles in European archaeology (GOTARC Series A, volume 1): 53-72. Gothenburg: University of Gothenburg.

ENGELHARDT, C. 1863. Thorsbjerg Mosefund. Sønderjyske og fynske Mosefund. Bind I. Kjøbenhavn: G.E.C. Gad.

FARBREGD, O. 2009. Archery history from ancient snow and ice, in T. Brattli (ed.) The $58^{\text {th }}$ International Sachsensymposium: 1-5 September 2007 (Vitark 7, Acta Archaeologica Nidrosiensia): 156-70. Trondheim: Tapir Akademisk.

Finstad, E. \& L. PiLø. 2010. Kulturminner og løsfunn ved isbreer og snøfonner i høyfjellet. Kulturhistoriske skrifter 2010: 52. Lillehammer: Oppland Fylkeskommune.

FuHRMANN, I. 1942. Zum Moorgewand von Reepsholt. Prähistorisches Zeitschrift 32-33: 339-65.

GrangER-TAYLOR, H. 1982. Weaving clothes to shape in the ancient world: the tunic and toga of the Arringatore. Textile History 13: 3-25.

Hald, M. 1980. Ancient Danish textiles from bogs and burials. Copenhagen: National Museum of Denmark.

Hansen, J.P.H., J. MeldgaARd \& J. Nordquist. 1985. Qilakitsoq. De Grønlandske mumier fra 1400-tallet. Nuuk \& Copenhagen: C. Ejler.

Hare, P.G., S. Greer, R. GotThardt, R. Farnell, V. BOWYER, C. SCHWEgER \& D. STRAND. 2004. Ethnographic and archaeological investigations of alpine ice patches in south-west Yukon, Canada. Arctic 57: 260-72.

International Organization for Standardization. 1981. International Standard ISO 4415: size designation of clothes - men's and boys' underwear, nightwear and shirts. Geneva: ISO.

Mallory, J.P. \& V.H. MaIr. 2000. The Tarim mummies. London: Thames \& Hudson.

Mannering, U., G. Possnert, J. Heinemeier \& M. GLeBA. 2010. Dating Danish textiles and skins from bogs by ${ }^{14} \mathrm{C}$ AMS. Journal of Archaeological Science 37: 261-68.

MÖller-Wiering, S. 2011. War and worship. Textiles from $3^{\text {rd }}$ to $4^{\text {th }}$ century $A D$ weapon deposits in Denmark and northern Germany. Oxford \& Oakville (CT): Oxbow.

PILø, L. Forthcoming. Brearkeologiske undersøkelser i Oppland 2010-2013.

Pritchard, F. 2006. Dress in Egypt in the first millennium $A D$. Manchester: Whitworth Art Gallery, University of Manchester.

RAST-EICHER, A. 2011. Tunic of Lendbreen/Norway: wool quality. Report prepared for the Museum of Cultural History, University of Oslo.

RÆder KNudsen, L. 2011. Tablet-woven textiles from $3^{\text {rd }}$ to $4^{\text {th }}$-century weapon deposits in Denmark and northern Germany, in S. Möller-Wiering War and worship. Textiles from $3^{\text {rd }}$ to $4^{\text {th }}$ century AD weapon deposits in Denmark and northern Germany: 163-98. Oxford \& Oakville (CT): Oxbow.

SCHLABOW, K. 1976. Textilfunde der Eisenzeit in Norddeutschland. Neumünster: Karl Wachholtz.

(C) Antiquity Publications Ltd. 
ShefFer, A. \& H. Granger-Taylor. 1994. Textiles from Masada. A preliminary selection, in Y. Yadin (ed.) Masada IV: the Yigael Yadin excavations 1963-1965. Final reports: 151-282. Jerusalem: Israel Exploration Society.

SPINDLER, K. 1995. Der Mann im Eis

(Veröffentlichungen des Forschungsinstituts für Alpine Vorzeit der Universität Innsbruck, volume 22). Wien: Springer.

Stauffer, A. 2012. Case study: the textiles from Verucchio, Italy, in M. Gleba \& U. Mannering (ed.) Textiles and textile production in Europe: from prehistory to $A D$ 400: 242-53. Oxford: Oxbow.

Suter, P., A. Hafner \& K. Glauser. 2005. Lenk-Schnidejoch. Funde aus dem Eis-ein vor-und frühgeschichtlicher Passübergang. Archäologie im Kanton Bern 6B: 499-522.
TAMERs, M.A. \& D.G. Hood. 2011. Report of radiocarbon dating analysis. Beta 304746, Beta Analytic Inc, Miami Florida. Report prepared for the Museum of Cultural History, University of Oslo.

WiLD, J.P., W.D. COOKE, C.R. CORK \& L. FANG LU. 1998. Vindolanda: some results of the Leverhulme Trust programme, in L. Bender Jørgensen \& C. Rinaldo (ed.) Textiles in European archaeology (GOTARC Series A, volume 1): 85-95. Gothenburg: University of Gothenburg.

Vogelsang-Eastwood, G. 1993. Pharaonic Egyptian clothing. Leiden: E.J. Brill.

VON POST, L., E. VON WALTERSDORFF \& S. LiNDQVIST. 1925. Bronsåldersmanteln frän Gerumsberget $i$ Västergötland. Stockholm: Kungliga Vitterhets Historie och Antikvitets Akademien.

Received: 12 June 2012; Accepted: 21 August 2012; Revised: 27 September 2012

(C) Antiquity Publications Ltd. 